\title{
Respiratory response in simultaneous exposure to flax and hemp dust
}

\author{
EUGENIJA ŽUŠKIN and F. VALIC \\ Andrija Stampar School of Public Health, Zagreb University, Zagreb, Yugoslavia
}

\begin{abstract}
Žuškin, E., and Valić, F. (1973). British Journal of Industrial Medicine, 30, 375-380. Respiratory response in simultaneous exposure to flax and hemp dust. The effect of exposure to high concentrations of mixtures of hemp and flax dust was studied in 124 workers in two textiie mills (mill A: $65-70 \%$ hemp and the rest flax, mean dust concentration $13.9 \mathrm{mg} / \mathrm{m}^{3}$; and mill B: about $35 \%$ hemp and the rest flax, mean dust concentration $15.8 \mathrm{mg} / \mathrm{m}^{3}$ ). A high prevalence of byssinosis was found in both mills $(80 \%$ in mill $\mathrm{B} ; 46.8 \%$ in mill A) after a mean exposure of no more than 13 years. In both mills, byssinotics had a higher prevalence of all chronic respiratory symptoms than non-byssinotics. This difference was more pronounced in mill A. Forty-eight percent of byssinotic women and $43 \%$ of byssinotic men had byssinosis of grade 2 or 3 . Significant mean acute reductions in $\mathrm{FEV}_{1.0}$ and $\dot{\mathrm{V}}_{\max } 50 \%$ VC on Monday were recorded in subjects with and without byssinosis with a significantly larger mean reduction in byssinotics $\left(\mathrm{FEV}_{1.0}, \mathrm{P}<0.01 ; \dot{\mathrm{V}}_{\max } 50 \% \mathrm{VC}, \mathrm{P}<0.05\right)$. $\dot{\mathrm{V}}_{\max }$ $50 \%$ VC proved to be a more sensitive test for detecting acute effects of vegetable dust than $\mathrm{FEV}_{1.0}$. The acute respiratory response of the subjects exposed to similar concentrations of flax and mixtures of two different proportions of flax and hemp dust was found to be equal.
\end{abstract}

It has already been reported that soft hemp and flax dus'i cause the development of byssinosis and other chronic respiratory symptoms accompanied by acute and chronic changes in ventilatory capacity (Bouhuys, Hartogensis, and Korfage, 1963; Carey and Merrett, 1965; Bouhuys et al., 1967; Valić et al., 1968). However, in only one paper have the effects of mixed exposure to hemp and flax dust on the respiratory function (Smith, Coles, Schilling, and Walford, 1969) been described. Acute respiratory response, however, was not studied in the paper. We are therefore reporting an investigation carried out in 124 workers exposed to mixed soft hemp and flax dust, comparing the results with those obtained in two previously studied groups of workers exposed to similar concentrations of pure hemp (Valić and Žuškin, 1971) and flax dust (Žuškin and Valić, 1973) respectively The mills included in the study processed flax and/or hemp grown in the same area of Yugoslavia and pretreated in the same way.

\section{Population and methods}

Population

In mill A the workers examined were exposed to dust consisting of about $65-70 \%$ soft hemp (Cannabis sativa) and the rest was flax dust (Linum usitatissimum). In mill B, the workers were mostly exposed to flax dust (about $65 \%$ ) and to a much lesser extent to hemp dust.

In mill $\mathbf{A}$, workers from carding and spinning departments were included in the study. Machines were located in two freely interconnecting rooms. In mill $B$, all the examined subjects worked on turbine scutchers in one large room.

The study was conducted in 64 female nonsmoking textile workers in mill A, and in a group of 40 female nonsmokers and 20 male smokers in mill B. The groups examined represented $96 \%$ of the workers engaged in the carding and spinning departments in mill $\mathrm{A}$ and $95 \%$ of the workers in mill $\mathrm{B}$. The mean age, height, and duration of exposure to hemp or flax dust are presented in Table 1.

Respiratory symptoms

Respiratory symptoms were recorded using the British 375 
Medical Research Council questionnaire on respiratory symptoms with additional questions on byssinosis (Schilling et al., 1963).

Chronic cough and/or phlegm: cough and/or phlegm production on most days for at least three months each year

Chronic bronchitis: cough with production of phlegm on most days for a minimum of three months in the year and for not less than two successive years

Clinical grades of byssinosis:

grade $\frac{1}{2}$-occasional chest tightness or difficulty in breathing at work on Mondays

grade $1-$ chest tightness and/or difficulty in breathing at work on every Monday

grade 2 -chest tightness and/or difficulty in breathing during work on Mondays and other working days grade 3-grade 2 accompanied by evidence of reduced ventilatory capacity

Dyspnoea :

grade 3-shortness of breath when walking with other people at an ordinary pace on the level grade 4-shortness of breath when walking at own pace on the level.

A detailed occupational history was taken from each subject, and standing height and weight were measured in all workers.

\section{Ventilatory function}

The one-second forced expiratory volume $\left(\mathrm{FEV}_{1 \cdot 0}\right)$ and maximum expiratory flow-volume (MEFV) curves were recorded before and after the work shift on the first working day of the week (Monday). $\mathrm{FEV}_{1.0}$ was measured on Bernstein type spirometers and corrected to BTPS. The average of the two highest $\mathrm{FEV}_{1 \cdot 0}$ values among four blows was taken as the result of the test. MEFV curves were recorded with a portable spirometer (Peters, Mead, and van Ganse, 1969). From the flow-volume curves the maximum flow rate at $50 \%$ of the control vital capacity $\left(\dot{\mathrm{V}}_{\max } 50 \% \mathrm{VC}\right)$, i.e., at $50 \%$ VC before the shift, was calculated. Out of the three MEFV curves obtained in each examinee the highest $\dot{\mathrm{V}}_{\max } 50 \% \mathrm{VC}$ was taken as the result of the test.

In each worker a bronchodilator (orciprenaline ${ }^{1}$ ) was administered at the end of the work shift to determine the degree of reversibility of the reduced ventilatory capacity. Each subject inhaled three doses of the aerosol from a pocket nebulizer (Dosier-Aerosol) delivering $750 \mu \mathrm{g}$ of active aerosol per puff. By applying three puffs and considering the aerosol penetration into the respiratory tract to be $70-75 \%$ (Zidek, 1963), the subject was exposed to a total dose of about $1.6 \mathrm{mg}$ orciprenaline. Ventilatory capacity measurements were repeated 15 minutes after the inhalation.

The values of $\mathrm{FEV}_{1.0}$ before the shift were compared with the normal predicted values calculated by the regression equations of Morris, Koski, and Johnson (1971).

\section{Dust measurement}

Dust was sampled by means of Hexhlet two-stage samplers with a horizontal laminal elutriator to determine total and fine dust concentrations separately (Wright, 1954). A filter was used as the second stage of the sampler. Eighteen dust samples were taken in mill A 'Alupent: 1-/3,5-dihydroxyphenyl-(2-isopropylaminoethanol sulphate). and 14 in mill $\mathbf{B}$. The periods of sampling were 1 to 3 hours.

\section{Statistical analysis}

The results of ventilatory function measurements were analysed by using the $t$ test for differences of paired and unpaired variables. The $\chi^{2}$ test was used for testing differences in the prevalence of respiratory symptoms. The results were considered significant when the probability of obtaining the results by chance alone was less than 0.05 .

\section{Results}

\section{Airborne dust concentrations}

The dust concentrations in mills $A$ and $B$ were found to be similar. The mean total dust concentration in mill A was $13.9 \mathrm{mg} / \mathrm{m}^{3}$ (range $7 \cdot 3-17.7 \mathrm{mg} / \mathrm{m}^{3}$ ) with the respirable fraction of $3.0 \mathrm{mg} / \mathrm{m}^{3}$ (range $0.5-5.9 \mathrm{mg} / \mathrm{m}^{3}$ ). In mill $\mathrm{B}$, the mean total and respirable dust concentrations were somewhat higher, i.e., $15 \cdot 8 \mathrm{mg} / \mathrm{m}^{3}$ (range $\left.10 \cdot 4-24 \cdot 2 \mathrm{mg} / \mathrm{m}^{3}\right)$ and $4 \cdot 5 \mathrm{mg} / \mathrm{m}^{3}$ (range $4 \cdot 3-6 \cdot 3 \mathrm{mg} / \mathrm{m}^{3}$ ).

\section{Respiratory symptoms}

The prevalence of chronic respiratory symptoms in workers in both mills is presented in Table 1. In mill A, $46.8 \%$ of female workers suffered from byssinosis. In mill $B$, a significantly larger proportion of workers $(\mathrm{P}<0.01)$ had clinical symptoms of byssinosis ( $80 \%$ for both men and women). The distribution of clinical grades of byssinosis is presented in Table 2 . The byssinosis grades $\frac{1}{2}$ or 1 were found in workers with a different length of exposure to hemp and flax, varying from 1 to 28 years, while all the workers with grade 2 or 3 had been exposed to this type of dust for more than seven years.

In byssinotics of mill $\mathbf{A}$, the prevalence of all the chronic respiratory symptoms (chronic cough $60.0 \%$, chronic phlegm $40.0 \%$, chronic bronchitis $33.3 \%$, and dyspnoea grade 3 or $430.0 \%$ ) was found to be significantly higher $(P<0.01)$ than in nonbyssinotics $(17 \cdot 6 \%, 5 \cdot 9 \%, 5 \cdot 9 \%, 2.9 \%$ respectively). Six byssinotic women $(20 \%$ of the byssinotic women in mill A) had dyspnoea grade 3 , and three $(10 \%)$ had grade 4. Among non-byssinotics only one woman $(2.9 \%)$ was found in dyspnoea grade 3 . The prevalence of nasal catarrh in these two groups was not significantly different.

In mill B, the women with byssinosis also had a higher prevalence of chronic respiratory symptoms than those without byssinosis, but the differences were not statistically significant $(P>0.05)$. The same was observed in men, the byssinotics having a considerably higher (but not statistically significant, $P>0.05)$ prevalence of chronic cough $(56.3 \%)$, chronic phlegm (56.3\%), chronic bronchitis $(56.3 \%)$, and dyspnoea (18.7\%) than those without byssinosis $\mathbf{2 5 . 0 \%}$ for chronic cough, chronic phlegm, and chronic bronchitis and none with dyspnoea). 
TABLE 1

Prevalence of Respiratory Symptoms

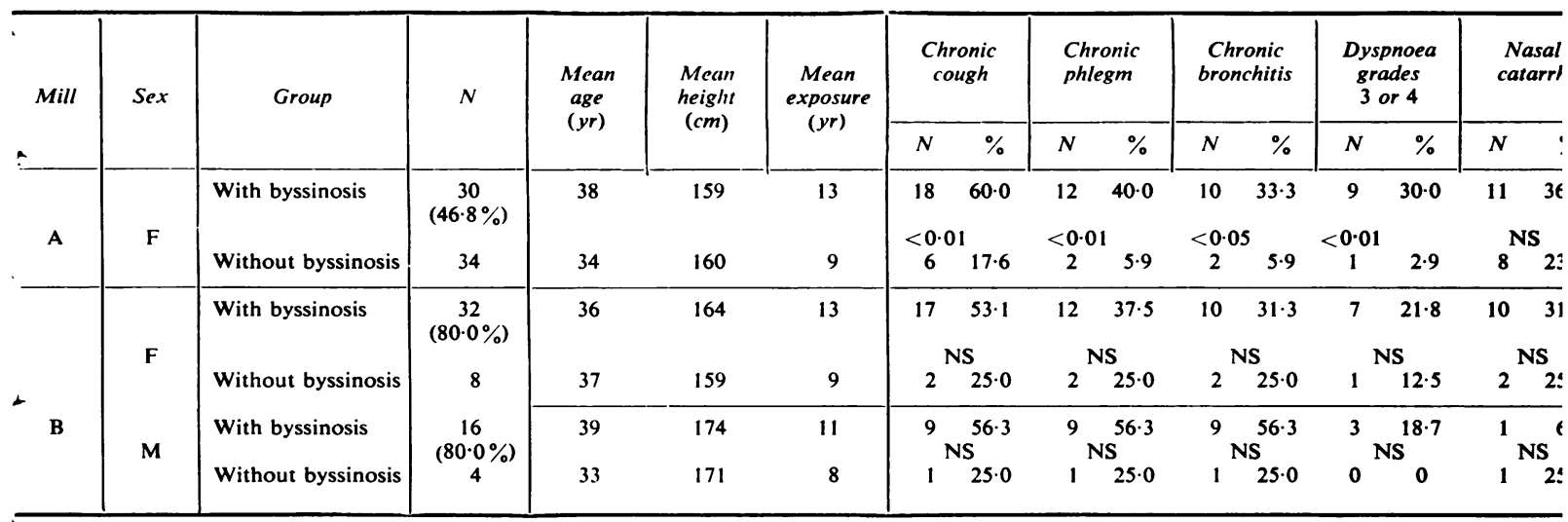

NS $=$ difference not significant $(P>0.05)$

TABLE 2

Clinical Grades of Byssinosis

\begin{tabular}{|c|c|c|c|c|c|c|c|c|c|}
\hline \multirow{3}{*}{ Mill } & \multirow{3}{*}{ Sex } & \multicolumn{8}{|c|}{ Grade of byssinosis } \\
\hline & & \multicolumn{2}{|c|}{$\frac{1}{2}$} & \multicolumn{2}{|c|}{1} & \multicolumn{2}{|c|}{2} & \multicolumn{2}{|c|}{3} \\
\hline & & $N$ & $\%$ & $N$ & $\%$ & $N$ & $\%$ & $N$ & $\%$ \\
\hline A & $\mathrm{F}$ & 3 & $10 \cdot 0$ & 13 & $43 \cdot 3$ & 10 & $33 \cdot 3$ & 4 & $13 \cdot 3$ \\
\hline B & $\begin{array}{l}\mathbf{F} \\
\mathbf{M}\end{array}$ & $\begin{array}{l}2 \\
1\end{array}$ & $\begin{array}{l}6 \cdot 3 \\
6 \cdot 3\end{array}$ & $\begin{array}{r}14 \\
8\end{array}$ & $\begin{array}{l}43 \cdot 8 \\
50 \cdot 0\end{array}$ & $\begin{array}{r}15 \\
6\end{array}$ & $\begin{array}{l}46 \cdot 8 \\
37 \cdot 5\end{array}$ & $\begin{array}{l}1 \\
1\end{array}$ & $\begin{array}{l}3 \cdot 1 \\
6 \cdot 3\end{array}$ \\
\hline
\end{tabular}

Pulmonary function

The mean forced expiratory volume in the first second (Table 3 ) decreased significantly during the first working day in all female workers and in male workers with byssinosis $(P<0.01)$. Because there were only four male workers without byssinosis the significance of their acute $\mathrm{FEV}_{1.0}$ drop was not tested. The mean $\dot{V}_{\max } 50 \%$ VC (Table 4) was significantly decreased over the work shift in all female workers in mill $\mathrm{A}$, and in male and female byssinotics in mill $\mathrm{B}(\mathrm{P}<0.01)$. The mean acute $\dot{\mathrm{V}}_{\max } 50 \%$ VC reduction in eight female nonbyssinotics in mill $\mathrm{B}$ was not significant $(P>0.05)$; in four male non-byssinotics the acute reductions in $\dot{\mathrm{V}}_{\max } 50 \%$ VC were not tested because of the small number of workers. The mean reductions in both tests were significantly greater in female workers with byssinosis than in those without byssinosis $\left(\mathrm{P}<0.01\right.$ for FEV 1.0 ; $P<0.05$ for $\dot{\mathrm{V}}_{\max } 50 \% \mathrm{VC}$ ). The difference in acute reductions in $\mathrm{FEV}_{\mathbf{1 . 0}}$ and $\dot{\mathrm{V}}_{\max } 50 \%$ VC between male workers with and without byssinosis was not tested, although the former had considerably larger acute reductions in both tests. A comparison of the mean acute reduction of $\dot{\mathrm{V}}_{\max } 50 \% \mathrm{VC}$ with the mean acute reduction of FEV $_{1.0}$ in female byssinotics showed that the relative change of $\dot{V}_{\max } 50 \%$ VC (mill A $-27.3 \%$; mill B $-21 \cdot 1 \%$ ) was significantly greater than that of $\operatorname{FEV}_{1.0}(-11.7 \%)(P<0.01)$. In non-byssinotics these differences were significantly different in mill A only $\left(\dot{\mathrm{V}}_{\max } 50 \%\right.$ VC $-13.9 \% ; \mathrm{FEV}_{1.0}-5.4 \%$; $\mathbf{P}<0.01)$. Male byssinotics also had a significantly larger mean reduction in $\dot{\mathrm{V}}_{\max } 50 \%$ VC $(25.0 \%)$ than in $\mathrm{FEV}_{1.0}(10.7 \%)(\mathrm{P}<0.01)$.

The application of the bronchodilator after the shift has shown that the acute reductions of ventilatory capacity are fully reversible in nonbyssinotics (Tables 3 and 4). In byssinotic women, in spite of a significant increase of both $F E V_{1.0}$ and $\dot{\mathrm{V}}_{\max } 50 \% \mathrm{VC}$ after the inhalation of a bronchodilator $(P<0.01)$, the mean ventilatory capacity after the shift still remained significantly lower than 
TABLE 3

Mean FEV 1.0 $_{\text {Changes on First Working Day in Week }}$

\begin{tabular}{|c|c|c|c|c|c|c|c|c|c|c|c|}
\hline \multirow{3}{*}{ Mill } & \multirow{3}{*}{ Sex } & \multirow{3}{*}{ Group } & \multirow{3}{*}{$N$} & \multirow{3}{*}{$\begin{array}{c}\text { Before } \\
\text { shift } \\
1\end{array}$} & \multirow{3}{*}{$\begin{array}{c}\text { After } \\
\text { shift } \\
2\end{array}$} & \multirow{2}{*}{\multicolumn{3}{|c|}{$\begin{array}{c}\text { Difference } \\
1-2\end{array}$}} & \multirow{3}{*}{$\begin{array}{c}\text { After } \\
\text { broncho- } \\
\text { dilator } \\
3\end{array}$} & \multicolumn{2}{|c|}{\begin{tabular}{cr}
\multicolumn{2}{c}{ Difference } \\
$2-3$ & $1-3$
\end{tabular}} \\
\hline & & & & & & & & & & & \\
\hline & & & & & & $m l$ & $\%$ & $P$ & & $P$ & $P$ \\
\hline \multirow{3}{*}{ A } & \multirow{3}{*}{$F$} & \multirow[t]{2}{*}{ With byssinosis } & \multirow[t]{2}{*}{30} & \multirow[t]{2}{*}{$\begin{array}{l}2617 \\
(2727)^{1}\end{array}$} & \multirow[t]{2}{*}{2310} & & $11 \cdot 7$ & $<0.01$ & 2561 & $<0.01$ & $<0.05$ \\
\hline & & & & & & $<0.01$ & & & & & \\
\hline & & $\begin{array}{l}\text { Without } \\
\text { byssinosis }\end{array}$ & 34 & $\begin{array}{c}2895 \\
(2954)^{\prime}\end{array}$ & 2739 & 156 & $5 \cdot 4$ & $<0.01$ & 2890 & $<0.01$ & NS \\
\hline \multirow{4}{*}{ B } & \multirow[b]{2}{*}{ F } & With byssinosis & 32 & $\begin{array}{c}2696 \\
(2691)^{1}\end{array}$ & 2379 & 317 & $11 \cdot 7$ & $=0.01$ & 2535 & $<0.01$ & $<0.01$ \\
\hline & & $\begin{array}{l}\text { Without } \\
\text { byssinosis }\end{array}$ & 8 & $\begin{array}{c}2571 \\
(2806)^{1}\end{array}$ & 2416 & $\begin{array}{r}<0.01 \\
155\end{array}$ & $6 \cdot 0$ & $<0.01$ & 2528 & $<0.01$ & NS \\
\hline & \multirow{2}{*}{$\mathbf{M}$} & & 16 & $\begin{array}{cl}3 & 175 \\
(3 & 303)^{1}\end{array}$ & 2836 & 339 & $10 \cdot 7$ & $<0.01$ & 3050 & $<0.01$ & NS \\
\hline & & $\begin{array}{l}\text { Without } \\
\text { byssinosis }\end{array}$ & 4 & $\begin{array}{c}3795 \\
(3782)^{x}\end{array}$ & 3695 & 100 & $2 \cdot 6$ & & 3855 & & \\
\hline
\end{tabular}

${ }^{\prime} \mathrm{FEV}_{1.0}$ values adjusted to standard age and height

NS $=$ difference not significant $(P>0.05)$

before the shift (mill A: $P_{F E V}<0.05, P_{V \max }<0.01$; mill B: $\left.P_{F E V}<0.01, P_{V \max }<0.05\right)$. In byssinotic men after the application of the bronchodilator the difference between the preshift and postinhalation values became statistically nonsignificant $(P>0.05)$, although some differences still remained.
In six women with symptoms of byssinosis in mill $\mathrm{A}$, the $\mathrm{FEV}_{1.0}$ on Monday before work was less than $80 \%$ of their respective normal $\mathrm{FEV}_{1.0}$ calculated by the regression equation of Morris et al. (1971). Of these, three were found with the FEV $_{1.0}$ less than $60 \%$ of the expected value. Only in one

TABLE 4

MeAN $\dot{V}_{\max } 50 \%$ VC Changes ON First Working Day IN WeEK

\begin{tabular}{|c|c|c|c|c|c|c|c|c|c|c|c|}
\hline \multirow{2}{*}{ Mill } & \multirow{2}{*}{ Sex } & \multirow{2}{*}{ Group } & \multirow{2}{*}{$N$} & \multirow{2}{*}{$\begin{array}{c}\text { Before } \\
\text { shift } \\
1\end{array}$} & \multirow{2}{*}{$\begin{array}{c}\text { After } \\
\text { shift } \\
2\end{array}$} & \multicolumn{3}{|c|}{$\begin{array}{c}\text { Difference } \\
1-2\end{array}$} & \multirow{2}{*}{$\begin{array}{c}\text { After } \\
\text { broncho- } \\
\text { dilator } \\
3\end{array}$} & \multicolumn{2}{|c|}{$\begin{array}{l}\text { Difference } \\
2-3 \quad 1-3\end{array}$} \\
\hline & & & & & & $l / \sec$ & $\%$ & $P$ & & $P$ & $P$ \\
\hline \multirow[t]{2}{*}{$\mathbf{A}$} & \multirow[t]{2}{*}{$\mathbf{F}$} & With byssinosis & 30 & $3 \cdot 3$ & $2 \cdot 4$ & $\begin{array}{r}0.9 \\
<0.05\end{array}$ & $27 \cdot 3$ & $<0.01$ & $2 \cdot 9$ & $<0.01$ & $<0.01$ \\
\hline & & byssinosis & 34 & $3 \cdot 6$ & $3 \cdot 1$ & 0.5 & 13.9 & $<0.01$ & $3 \cdot 5$ & $<0.01$ & NS \\
\hline \multirow{3}{*}{ B } & \multirow[t]{2}{*}{ F } & With byssinosis & 32 & $3 \cdot 8$ & $3 \cdot 0$ & $\begin{array}{r}0.8 \\
<0.05\end{array}$ & $21 \cdot 0$ & $<0.01$ & $3 \cdot 5$ & $<0.01$ & $<0.05$ \\
\hline & & $\begin{array}{l}\text { Without } \\
\text { byssinosis }\end{array}$ & 8 & $4 \cdot 2$ & 3.9 & 0.3 & $7 \cdot 1$ & NS & $4 \cdot 4$ & $<0.05$ & NS \\
\hline & $\mathbf{M}$ & $\begin{array}{l}\text { With byssinosis } \\
\text { Without } \\
\text { byssinosis }\end{array}$ & 16 & $4 \cdot 4$ & $3 \cdot 3$ & $1 \cdot 1$ & $25 \cdot 0$ & $<0.01$ & $4 \cdot 1$ & $<0.01$ & NS \\
\hline
\end{tabular}

NS $=$ difference not significant $(P>0.05)$ 
woman without byssinosis was the $\mathrm{FEV}_{\mathrm{1.0}}$ less than $80 \%$ of the expected value. In mill $\mathrm{B}$ among female workers with symptoms of byssinosis, seven were found with the Monday preshift FEV $_{1.0}$ less than $80 \%$ of the normal FEV 1.0 . In four of these women the $\mathrm{FEV}_{1.0}$ was less than $60 \%$ of the expected $\mathrm{FEV}_{\text {1.0. }}$. Among non-byssinotics in mill $\mathrm{B}$, only in one woman was the preshift $\mathrm{FEV}_{1.0}$ less than $80 \%$ of the expected value. In five male byssinotics the preshift $\mathrm{FEV}_{1.0}$ was less than $70 \%$ of the normal $\mathrm{FEV}_{1.0}$. Among four men without byssinosis, none was found with the $\mathrm{FEV}_{1.0}$ less than $80 \%$ of the expected value.

In order to find out whether there is a difference in chronic effects on the ventilatory capacity between byssinotics and non-byssinotics their mean preshift FEV $_{1.0}$ values (before the superimposed acute effect of dust over the shift) were compared. As the height and age distributions of the workers in these two groups were not identical, it was considered unjustifiable directly to compare their mean preshift $\mathrm{FEV}_{\mathbf{1 . 0}}$ values. All the preshift $\mathrm{FEV}_{1.0}$ data of the female workers were therefore adjusted to a standard age of 36 years and a standard height of $162 \mathrm{~cm}$, and those of the male examinees to a standard age of 36 years and a standard height of $172 \mathrm{~cm}$, using a multiple linear regression equation of the type $y=a+b \times$ age $+c \times$ height $\left(y-F_{1.0} ; a, b, c-\right.$ regression coefficients). The adjusted means are shown in Table 3 in parentheses. The mean adjusted Monday preshift values were found to be significantly lower $(\mathrm{P}<0.05)$ in byssinotics than in nonbyssinotics in the examined group of women in mill A. In mill B, this difference was not statistically significant $(P>0.05)$. The men with byssinosis had a considerably lower adjusted mean preshift FEV $_{1.0}$ (3 $303 \mathrm{ml}$ ) than those without byssinosis $(3782 \mathrm{ml})$ but this difference was not tested for significance because of the small number of non-byssinotic workers.

There was no difference in the mean acute $\mathrm{FEV}_{1.0}$ reduction over the shift between byssinotic female workers with or without chronic bronchitis in mill A (13.1 and $12.8 \%$ respectively), while female byssinotics with chronic bronchitis had slightly larger $\mathrm{FEV}_{1.0}$ reductions $(11.9 \%)$ than those without chronic bronchitis $(9.7 \%)$ in mill B. Male byssinotics with chronic bronchitis, however, had a considerably larger mean $\mathrm{FEV}_{1.0}$ reduction $(13.5 \%)$ than those without chronic bronchitis $(6 \cdot 9 \%)$.

\section{Discussion}

In contrast to the findings of Smith et al. (1969), who reported only six cases of byssinosis in their group of 54 men and 22 women exposed to mixed soft hemp and flax dust (byssinosis prevalence $7.9 \%$ ), we have found a byssinosis prevalence of $45.8 \%$ and
$80 \%$ respectively in the two plants studied, in spite of a shorter duration of total exposure to dust in our groups. The mean duration of dust exposure in our group was 11 years for men and 13 years for women while the byssinotic subjects reported by Smith et al. (1969) had long exposures ranging from 16 to 44 years (except for one with two years' exposure only). Such a substantial difference in the findings is undoubtedly due primarily to a great difference of exposure levels. The average airborne dust concentrations of 13.9 and $15.8 \mathrm{mg} / \mathrm{m}^{3}$ respectively in the workrooms we studied were 8 to 10 times as high as the average concentration in the dustier parts of the English factory described by Smith et al. (1969). Under such a heavy exposure to an active vegetable dust a high prevalence of byssinosis was to be expected. The distribution of clinical grades of byssinosis of our cases (Table 2) gives an insight into the severity of the disease. Over $48 \%$ of byssinotic women and over $43 \%$ of byssinotic men had byssinosis grades 2 or 3 . All had been exposed to dust for more than seven years.

The prevalence of chronic respiratory symptoms (chronic cough, chronic phlegm, chronic bronchitis, dyspnoea grades 3 or 4) was considerably higher in subjects with than in those without byssinosis (Table 1), indicating an association between the development of byssinosis and a nonspecific respiratory impairment in mixed hemp and flax exposure.

Exposure to mixed soft hemp and flax dust causes a significant acute reduction of ventilatory capacity over the shift which is considerably more pronounced in subjects with byssinosis (Tables 3 and 4). $\dot{\mathrm{V}}_{\max }$ $50 \% \mathrm{VC}$ proved to be a significantly more sensitive test of this reduction than $F V_{1.0}$, indicating that the effect of the inhaled mixed hemp and flax dust is more pronounced in small airways.

In order to evaluate the relative effects of soft hemp, flax, and mixed hemp and flax on ventilatory capacity we have compared the acute $F E V_{1.0}$ drops over the shift measured in four groups of nonsmoking female workers exposed to similar concentrations of hemp dust, flax dust, mixed hemp and flax dust containing approximately $65-70 \%$ hemp, and mixed hemp and flax dust with approximately $35 \%$ hemp, respectively. The mean total exposures to dust in the four groups were almost identical. The number of workers, mean total and respirable dust concentrations, mean lengths of exposure to dust, and the

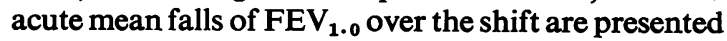
in Table 5. Hemp and flax used in the plants with flax and mixed hemp and flax exposures were grown in the same area in northern Yugoslavia in the same season (1970-71) while hemp in the plant with pure hemp exposure was grown in the same area but in 1967-68.

The acute respiratory response of the subjects exposed to similar concentrations of flax and mixtures 
TABLE 5

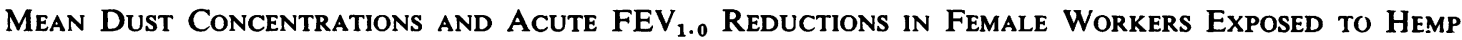
Flax, and Mixed Hemp and Flax Dust

\begin{tabular}{|c|c|c|c|c|c|c|}
\hline \multirow{2}{*}{$\begin{array}{l}\text { Exposure } \\
\text { group }\end{array}$} & \multirow{2}{*}{$N$} & \multicolumn{2}{|c|}{$\begin{array}{c}\text { Mean dust concentration } \\
\left(\mathrm{mg} / \mathrm{m}^{3}\right)\end{array}$} & \multirow{2}{*}{$\begin{array}{l}\text { Mean } \\
\text { exposure } \\
(y r)\end{array}$} & \multicolumn{2}{|c|}{$\Delta \mathrm{FEV}_{1 \cdot 0}$} \\
\hline & & Total & Respirable & & $m l$ & $\%$ \\
\hline $\begin{array}{l}\text { Mixed A (65-70\% hemp) } \\
\text { Mixed B }(65 \% \text { flax }) \\
\text { Hemp } \\
\text { Flax }^{2}\end{array}$ & $\begin{array}{r}64 \\
40 \\
102 \\
55\end{array}$ & $\begin{array}{l}13.9 \\
15.8 \\
16.2 \\
16.9\end{array}$ & $\begin{array}{l}3 \cdot 0 \\
4 \cdot 5 \\
1 \cdot 8 \\
3 \cdot 4\end{array}$ & $\begin{array}{l}11 \\
12 \\
10 \\
11\end{array}$ & $\begin{array}{l}-234 \\
-253 \\
-425 \\
-234\end{array}$ & $\begin{array}{l}-8.5 \\
-9.5 \\
-15.4 \\
-9.0\end{array}$ \\
\hline
\end{tabular}

1Valić and Žuškin (1971)

'Žuškin and Valić (1973).

of flax and hemp in two different proportions (roughly $1: 2$ and $2: 1$ ) was found to be practically identical $\left(8 \cdot 5-9 \cdot 5 \% \mathrm{FEV}_{1.0}\right.$ fall over the shift). The acute response to pure hemp exposure was much greater $\left(\mathrm{FEV}_{1.0}\right.$ fall $\left.15.4 \%\right)$ but it would be unjustifiable to compare this effect with the effects of other exposures as the hemp grown in 1967-68 might have been pharmacologically more potent and might therefore have caused a more intense histamine liberation from lung tissue and, consequently, a stronger smooth muscle contraction and a subsequently higher reduction of ventilatory capacity.

Slightly in contrast to our previous results (Valić and Žuskin, 1972), the smooth muscle contracting potency (possibly direct and indirect through histamine release) of our 1970-71 hemp and flax was practically equal, while that of the 1967-68 hemp seems to have been considerably stronger. Experiments are in progress to verify this hypothesis pharmacologically (on smooth muscle preparations) and biochemically (histamine release determination). At the moment the hypothesis is based on indirect evidence obtained from a comparison of the relative acute respiratory responses of workers exposed to the respective dust.

There is no doubt that exposure to a high concentration of mixed hemp and flax dust represents an occupational health hazard equal to that produced by exposure to pure active hemp or flax dust. Exposure causes the development of byssinosis in a considerable proportion of workers and may eventually lead to the development of chronic respiratory impairment.

\section{References}

Bouhuys, A., Barbero, A., Lindell, S. E., Roach, S. A., and
Schilling, R. S. F. (1967). Byssinosis in hemp workers. Archives of Environmental Health, 14, 533-544.

—, Hartogensis, F., and Korfage, H. J. H. (1963). Byssinosis prevalence and flax processing. British Journal of Industrial Medicine, 20, 320-323.

Carey, G. C. R., and Merrett, J. D. (1965). Changes in ventilatory capacity in a group of flax workers in Northern Ireland. British Journal of Industrial Medicine, 22, 121-127.

Morris, J. F., Koski, A., and Johnson, L. C. (1971). Spirometric standards for healthy nonsmoking adults. American Review of Respiratory Diseases, 103, 57-67.

Peters, J. M., Mead, J., and van Ganse, W. F. (1969). A simple flow-volume device for measuring ventilatory function in the field. American Review of Respiratory Diseases, 99, 617-622.

Schilling, R. S. F., Vigliani, E. C., Lammers, B., Valić, F., and Gilson, J. C. (1963). A report on a conference on byssinosis. Proceedings of the International Congress of Occupational Health, Madrid, vol. 2, pp. 137-145. Excerpta Medica Foundation, Amsterdam.

Smith, G. F., Coles, G. V., Schilling, R. S. F., and Walford, J. (1969). A study of rope workers exposed to hemp and flax. British Journal of Industrial Medicine, 26, 109-114.

Valić, F., and Žuškin, E. (1971). Effects of hemp dust exposure on nonsmoking female textile workers. Archives of Environmental Health, 23, 359-364.

- , and - (1972). Effects of different vegetable dust exposures. British Journal of Industrial Medicine, 29, 293-297.

- - Walford, J., Keršić, W., and Pauković, R. (1968). Byssinosis, chronic bronchitis, and ventilatory capacities in workers exposed to soft hemp dust. British Journal of Industrial Medicine, 25, 176-186.

Wright, B. M. (1954). A size-selecting sampler for airborne dust. British Journal of Industrial Medicine, 11, 284-288.

Zidek, R. (1963). Pneumometrische Untersuchungen und klinische Beobachtungen über den bronchospasmolytischen Effekt eines neuen antiasthmatischen SprühdosenInhalats. Medizinische Welt (Stuttgart), pp. 1421-1427.

Žuškin, E., and Valić, F. (1973). Respiratory changes in two groups of flax workers with different exposure pattern. Thorax, 28, 579-583.

Received for publication January 30, 1973. 